IRA-International Journal of Education \& Multidisciplinary Studies

ISSN 2455-2526; Vol.04, Issue 01 (2016)

Institute of Research Advances

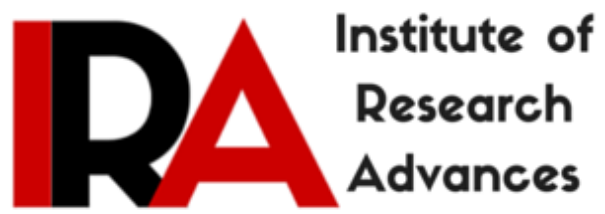

http://research-advances.org/index.php/IJEMS

\title{
New Functions of Higher Education in Achieving Education for all
}

Dr. Niranjani Chaurasia

Assistant Professor, Department of Chemistry

Sri J.N.P.G. College, Lucknow, U.P. India.

DOI: http://dx.doi.org/10.21013/jems.v4.n1.p17

\section{How to cite this paper:}

Chaurasia, N. (2016). New Functions of Higher Education in Achieving Education for all. IRA International Journal of Education and Multidisciplinary Studies (ISSN 24552526), 4(1). doi:http://dx.doi.org/10.21013/jems.v4.n1.p17

(C) Institute of Research Advances

\section{(cc) EY-NC}

This works is licensed under a Creative Commons Attribution-Non Commercial 4.0 International License subject to proper citation to the publication source of the work.

Disclaimer: The scholarly papers as reviewed and published by the Institute of Research Advances (IRA) are the views and opinions of their respective authors and are not the views or opinions of the IRA. The IRA disclaims of any harm or loss caused due to the published content to any party. 


\begin{abstract}
Higher education is at the top of the education pyramid and determines to a large extent the state of the education system of the country, especially its quality. As such it has a responsibility towards the whole education system as it has towards the whole of society.

The World Conference on Higher Education has one of the missions and functions of higher education: "to contribute to the development and improvement of education at all levels, including through training of teachers."

Higher education has an important role to play through its graduates who should provide leadership roles in education as researchers, teachers, consultants and managers, who should create and apply new knowledge and innovations, and who should provide analytical perspectives on development problems and service to public and private sectors.

Higher education through its research function could identify the preconditions for a supportive policy context for the development of basic education and explore techniques of mobilizing resources. Through its research, training and service programmes (the three principal functions), it could contribute to build national technical capacity and contribute to strengthening international solidarity.

In particular, to promote basic education for all, higher education through its three principal functions, could improve access and equity in basic education, its quality and relevance and improve its efficiency and management.
\end{abstract}

\title{
INTRODUCTION
}

Higher education determines to a large extent the state of the education system of the country, especially its quality. As such it has a responsibility towards the whole education system as it has towards the whole of society.

Achieving education for all should therefore be one of the responsibilities of the higher education system. However, in reality higher education has been concerned mainly with human resource development for the modern economic sector, has served the elites of the society and has produced elites. "Institutions of higher education (IHEs) in developing countries have mostly kept to their traditional functions and objectives, and the 'ivory tower' idea that they should only deal with theoretical knowledge, show interest to the formulation of theory and research, and value knowledge ownership and preservation idea." It has hardly concerned itself with other levels and types of education except through some ad hoc individual efforts without any institutional mechanism. Paradoxically, the foundation for education, which lays at the basic education level, has been ignored to make the whole education system weak and fragile.

Higher education through its research function could identify the preconditions for a supportive policy context for the development of basic education and explore techniques of mobilizing resources. Through its research, training and service programmes (the three principal functions), it could contribute to build national technical capacity and contribute to strengthening international solidarity. 


\section{METHODOLOGY}

\section{Tasks of Higher education Institution (HEI) to promote "Education for All}

\section{(a) To improve access and equity in basic education}

Education and 1. Introduce teaching of local languages and ICT literacy for potential teachers. training

2. Reinforce teacher education and teacher management training, especially female teachers for basic education.

3. Introduce teaching of cultural factors promoting education.

4. Introduce teaching of educational planning, especially in formulating access policies and equity policies for basic education.

5 Introduce affirmative action for admitting female students and students of lower socio-economic status in the teacher education programmes.

6 Introduce distance learning and learning through suitable ICT to reach the unreached

II. Research

1. Investigate the effect of medium of instruction on motivating children of lower socio-economic status to pursue basic education and literacy programmes.

2. Investigate the role of culture on demand for education for children of different socio-economic status, especially girls.

3. Investigate the reasons for children remaining out of school, dropping out of school and failing examinations at the basic education level and formulate policies for achieving greater access and equity.

III. Services $\quad 1$. Initiate adult literacy classes in campus.

2. Introduce national service for students to teach in basic education schools as a condition for graduation.

3. Launch campaign through media and other means in extra mural studies department for motivating and encouraging children of lower socioeconomic status and women to pursue basic education. 


\section{(b) To improve quality and relevance of basic education}

I. Education and 1. Train teachers for teaching/training materials suitable for local contexts training and environment.

2. Involve the community in designing content, method and structure of teacher training so that basic education can make school leavers employable either in the formal or in the informal sector.

3. Modernize teacher training taking into account the development of ICT and new pedagogy.

4. Introduce courses on methods of assessing quality and relevance of basic education and their improvement.

5. Introduce in-service courses on teacher management for heads and managers of basic education programmes.

6. Introduce training programmes on how to conceive, produce, distribute and evaluate textbooks cost effectively.

II. Research

1. Investigate the status of quality and relevance of basic education programmes (content, method and structure) through the perception and experience of the parents, the community and the employers.

2. Investigate the reasons for lack of quality and relevance and formulate policies for improvement.

3. Investigate the needs for skills of basic education completers in the labour market, formal and informal, and formulate policies for education, training and service departments of the Institution.

4. Investigate the difference in quality and relevance of education offered by different methods.

5. Evaluate and monitor the progress made in 'basic education for all'.

III. Services 1. Organize evenings for the community within the 'extra mural studies department' to discuss the usefulness and the quality of the basic education programmes in so far as they concern the institution of higher education (e.g. adult literacy programme of the department, the training of teachers, the standard of the content of the training materials prepared within the institution of higher education, etc.).

2. Prepare programmes of neo-literates for the media for sustainability of education received.

\section{(c) To improve efficiency/finance/management of basic education}

I. Education and1. Introduce courses for heads of schools/programmes in educational training planning and management, focusing on ways of better utilization of resources, financing of programmes through community participation and other means and on school management and management of programmes at the national, provincial and local levels. 
II. Research

1. To prepare state of the art papers on 'good practices' in efficiency, financing and management of basic education and literacy programmes from around the world.

2. Investigate the roles of the State, the community and the school in improving management of basic education and literacy

3. Identify reasons for inefficiency and wastage of resources (including student and staff time) and formulate corrective measures (e.g. demotivation of teachers and corrective measures; internal and external inefficiency and methods of reducing them using new technology where applicable) .

4. Investigate cost-effectiveness of alternative delivery systems for different target groups

5. Assist the government to prepare a 'viable and sustainable plan for achieving education for all' to mobilize funds from international agencies.

III. Services 1. Organize 'open door' evenings for meetings with the community to identify any inefficiency perceived and experienced by them and discuss possible means of correcting them.

2. Organize meetings with potential donors to finance programmes of improving basic education.

3. Organize evening in-service classes for school and programme managers inviting extension lecturers on educational management.

\section{CONCLUSION \& DISCUSSION}

This is a review of the various higher education institutions survey. For higher education to be successful in undertaking the above tasks, a supportive policy context for itself is needed and that would call for extensive and intensive reform in higher education. The role of higher education has to be developmental and transformative and not just fitting individuals in the labour market. For that to happen, its management has to be improved so that it can function efficiently with, at least, minimum basic resources. The development of basic education and literacy should be an explicitly recognized function of higher education as instruction, research and public service. An institutional framework for the development of basic education is essential within the institutions of higher education.

\section{REFERENCES}

- Delores, J et al, Learning: the treasure within. Paris, UNESCO, 1996

- World Conference on Higher Education, Higher Education in the Twenty First Century, Final Report. Paris, UNESCO, October 1998

- DAE (now ADEA), Working Group Meeting on Higher Education. Paris, DAE, 1995.

- MalcolmSkilbeck, Education for all - global synthesis, EFA international consultative forum documents 